\title{
AKTIVITAS ANTIOKSIDAN PROTEIN HIDROLISAT DARI KASEIN SUSU KAMBING ETAWA HASIL HIDROLISIS BROMELIN DARI DAUN NANAS MADU
}

\author{
Antioxidant Activity of Hydrolyzate Protein from Etawa Goat Milk Casein \\ Hydrolysed Using Honey Pineapple Leaf Bromelain
}

\author{
Puji Lestari ${ }^{1)}$ dan Suyata ${ }^{1)}$ \\ 1) Jurusan Kimia Fakultas Matematika dan Ilmu Pengetahuan Alam \\ Universitas Jenderal Soedirman, Purwokerto \\ Email: pujilest1974@gmail.com
}

\begin{abstract}
Hydrolyzed proteins are fragments of protein fragments that have certain biological activities. Some of the functions of hydrolyzed proteins that are known are as antibacterial, antioxidant, antihypertensive, antithrombotic, anti-inflammatory, opioid, and immunomodulatory. Protein from Etawa goat's milk is one source of protein hydrolyzate. In this research, the antioxidant activity of protein hydrolyzate from casein Etawa goat milk was tested. Casein is hydrolyzed with bromelain from honey pineapple leaves. The research steps are: bromelain extraction, casein hydrolysis of Etawa goat milk, antioxidant activity fraction of hydrolyzed protein fractions by DPPH method, and hemolysis test. The results of the study were: (1) the highest degree of hydrolysis in casein hydrolyzate was achieved at 60 minutes incubation time, (2) casein hydrolyzate which had the highest antioxidant activity was incubated for 30 minutes, (3) based on the AAI value, the casein hydrolyzed activity included into the classification of weak antioxidants because AAI $<0.5$, (4) the results of the hemolysis test show that casein hydrolyzate does not cause hemolysis of red blood cells.
\end{abstract}

Keyword: antioxidant, bromelain, etawa goat milk, hemolysis, hydrolysate protein

\begin{abstract}
ABSTRAK
Protein hidrolisat merupakan fragmen pecahan protein yang memiliki aktivitas biologis tertentu. Beberapa fungsi protein hidrolisat yang telah diketahui adalah sebagai antibakteri, antioksidan, antihipertensi, antitrombosis, antiinflamatori, opioid, dan imunomodulator. Protein dari susu kambing Etawa merupakan salah satu sumber protein hidrolisat. Pada penelitian ini, dilakukan uji aktivitas antioksidan protein hidrolisat dari kasein susu kambing Etawa. Kasein dihidrolisis dengan bromelin dari daun nanas madu. Tahap penelitian yang dilakukan adalah: ekstraksi bromelin, hidrolisis kasein susu kambing Etawa, uji aktivitas antioksidan fraksifraksi protein hidrolisat dengan metode DPPH, dan uji hemolisis. Hasil penelitian adalah: (1) derajat hidrolisis tertinggi pada kasein hidrolisat dicapai pada waktu inkubasi 60 menit, (2) kasein hidrolisat yang memiliki aktivitas antioksidan tertinggi adalah yang diinkubasi selama 30 menit, (3) berdasarkan nilai AAI, maka aktivitas antioksidan kasein hidrolisat termasuk ke dalam klasifikasi antioksidan lemah karena AAI < 0,5, (4) hasil uji hemolisis menunjukkan bahwa kasein hidrolisat tidak menyebabkan terjadinya hemolisis terhadap sel darah merah.
\end{abstract}

Kata Kunci: antioksidan, bromelin, hemolisis, protein hidrolisat, susu kambing etawa

\section{PENDAHULUAN}

Peptida bioaktif merupakan fragmen pecahan protein dengan urutan dan komposisi asam amino tertentu yang memiliki aktivitas biologis tertentu setelah dilepaskan dari proteinnya oleh kerja enzim. Menurut Mora \& Toldra (2014), peptida bioaktif memiliki 2-20 asam 
amino dengan massa molekul kurang dari 6000 Da. Bioaktivitas peptida ditentukan oleh komposisi dan urutan asam aminonya. Beberapa peptida bioaktif telah diketahui memiliki aktivitas biologi di dalam tubuh seperti antioksidan, antihipertensi, antitrombosis, antiadipogenik, antimikroba, antiinflamasi dan efek immunomodulatori (Ahn et al., 2015). Peptida bioaktif bisa didapatkan dari protein tanaman dan hewan. Sumber peptida bioaktif dari tanaman umumnya berasal dari kelompok biji-bijian seperti gandum, beras, oats, rye, jagung, dan kelompok kacang-kacangan seperti kedele, kacang polong, dan chickpeas (Martinez et al., 2012). Daging, telur, susu, dan ikan adalah sumber peptida bioaktif dari hewan (Sabahelkheir et al., 2012).

Susu merupakan salah satu sumber peptida bioaktif dengan fungsi biologis yang sangat luas (Szwajkowska et al., 2011). Belum banyak penelitian yang melaporkan mengenai pemanfaatan protein susu kambing sebagai sumber peptida bioaktif (Li et al., 2013). Susu kambing memiliki kandungan protein yang tinggi yakni sebesar 3,4 \% (Park et $a l ., 2007)$. Kandungan protein yang tinggi pada susu kambing dan hasil hidrolisisnya berupa peptida mempunyai fungsi biologis yang luas (Szajkwoska et al.,
2011). Faktor yang sangat mempengaruhi keberhasilan dalam mendapatkan potongan-potongan peptida bioaktif adalah sumber protein serta spesifisitas enzim. Oleh karena itu, pemilihan enzim menjadi tahap yang sangat penting karena sangat mempengaruhi bioaktivitas dari potongan-potongan peptida yang dihasilkan (Kumar et al., 2013).

Pada penelitian ini, dilakukan uji aktivitas antioksidan protein hidrolisat dari kasein susu kambing Etawa. Hidrolisis kasein dilakukan dengan enzim bromelin dari daun nanas madu dengan variasi waktu hidrolisis yang berbeda. Setiap fraksi protein hidrolisat dari kasein ditentukan derajat hidrolisisnya, diuji aktivitas antioksidan dengan metode DPPH, dan uji hemolisis terhadap sel darah merah.

\section{Metode}

Alat

Alat-alat yang digunakan dalam penelitian ini adalah peralatan gelas laboratorium, freeze dryer Virtish model Benchtop 2K XL, oven memmert, penangas, mortar porselen, mikropipet socorex 100-1000 $\mu \mathrm{L}$, mikropipet socorex 5-50 $\mu \mathrm{L}$, water bath precision 283, spektrofotometer Shimadzu UV1800, pH meter, sentrifus Ohaus, sentrifus 80-2, lemari pendingin, neraca 
analitik, sentrifus TG16-W, dan kertas saring.

\section{Bahan}

Bahan-bahan yang digunakan pada penelitian ini adalah susu kambing Etawa dari peternak lokal Desa Purbadana Kecamatan Kembaran Banyumas, daun dari nanas madu asal Desa Beluk Kecamatan Belik Kabupaten Pemalang, tirosin, kasein, $\mathrm{Na}_{2} \mathrm{CO}_{3}, \quad \mathrm{CuSO}_{4}$, $\mathrm{NaH}_{2} \mathrm{PO}_{4} \cdot 2 \mathrm{H}_{2} \mathrm{O}, \quad \mathrm{Na}_{2} \mathrm{HPO}_{4} 2 \mathrm{H}_{2} \mathrm{O}$, $\mathrm{C}_{4} \mathrm{H}_{11} \mathrm{O}_{3} \mathrm{~N}, \mathrm{CH}_{3} \mathrm{COOH}$, metanol, Na-K tartat, folin ciocalteu, $\mathrm{HCl}, \mathrm{NaCl}, \mathrm{NaOH}$, TCA, DPPH, darah ayam, Tween 80, Tris salin, asam oksalat, vitamin C p.a, dan akuades.

\section{Prosedur Penelitian}

\section{Ekstraksi bromelin (Darwis dan}

Sakara, 1990)

Enzim bromelin diekstraksi dengan cara menumbuk 100 gram daun nanas madu menggunakan mortar dan alu pada kondisi dingin. Filtrat diambil dengan cara diperas menggunakan kain muslin, kemudian ditambahkan dengan $100 \mathrm{~mL}$ bufer fosfat $0,1 \mathrm{M} \mathrm{pH} 7$. Bagian-bagian yang tidak larut dalam filtrat, dipisahkan dengan cara sentrifugasi dengan kecepatan 12.000 rpm selama 15 menit pada suhu $4{ }^{\circ} \mathrm{C}$. Supernatan yang diperoleh adalah ekstrak kasar enzim bromelin.

\section{Preparasi susu kambing (Yoshida et al., 2000; Bezerra et al., 2013)}

Susu kambing etawa segar disentrifugasi selama 15 menit dengan kecepatan $12.000 \mathrm{rpm}$ pada suhu $4{ }^{\circ} \mathrm{C}$ untuk memisahkan lemak dari protein susu. Pasteurisasi susu dilakukan menggunakan metode High Temperature Short Time (HTST), yaitu pemanasan susu selama 15 detik pada suhu $72^{\circ} \mathrm{C}$. Isolasi kasein dari protein susu kambing dilakukan dengan menambahkan $\mathrm{HCl} 2 \mathrm{~N}$ pada suhu $40{ }^{\circ} \mathrm{C}$ ke dalam susu yang sudah dipasteurisasi hingga mencapai titik isoelektrik $(\mathrm{pH}$ 4,6). Susu disentrifugasi kembali dengan kecepatan 12.000 rpm selama 15 menit untuk memisahkan kasein dan whey. Pellet yang dihasilkan adalah kasein, sedangkan dari supernatan dihasilkan adalah whey. Kasein dibilas dengan akuades sebanyak 1 kali, kemudian dilarutkan dalam bufer fosfat 0,05 M pH 7 dengan konsentrasi kasein $10 \mathrm{mg} / \mathrm{mL}$

\section{Hidrolisis susu kambing}

(Kusumaningtyas et al., 2015; Lestari dan Soesilo, 2017)

Substrat kasein dari susu kambing peranakan etawa dihidrolisis menggunakan ekstrak kasar bromelin pada kondisi optimum (suhu $55^{\circ} \mathrm{C}$ dan 
pH 7). Perbandingan enzim dan substrat yang digunakan adalah 1:4. Hidrolisis dilakukan dengan interval waktu 10, 20, 30, 40, 50, dan 60 menit. Kontrol adalah kasein yang tidak dihidrolisis. Hidrolisis dihentikan dengan pemanasan pada suhu $80{ }^{\circ} \mathrm{C}$ selama 15 menit. Substrat kasein yang telah dihidrolisis disaring menggunakan kertas saring, kemudian diuji aktivitas antioksidannya.

\section{Derajat Hidrolisis}

Derajat hidrolisis ditentukan dengan mengukur kadar protein sebelum dan setelah dihidrolisis. Penentuan kadar protein dilakukan menggunakan metode Lowry (Bollag et al., 1996). Sebanyak 1 $\mathrm{mL}$ protein hidrolisat dari kasein ditambah dengan $5 \mathrm{~mL}$ reagen Lowry $\mathrm{C}$, dikocok dan diinkubasi selama 10 menit pada suhu ruang. Campuran larutan ditambah $0,5 \mathrm{~mL}$ reagen Lowry E, diinkubasi pada suhu ruang selama 30 menit sambil sekalisekali dikocok. Larutan diukur absorbansinya pada panjang gelombang 750 nm. Kadar protein dihitung berdasarkan persamaan regresi linear dari kurva standar kasein. Derajat hidrolisis dihitung menggunakan persamaan:

Derajat Hidrolisis $=\frac{\mathrm{KP} \text { awal }-\mathrm{KP} \text { akhir }}{\mathrm{KP} \text { awal }} \mathrm{X}$ $100 \%$

Keterangan:
$\mathrm{KP}$ awal $=$ kadar protein kasein sebelum dihidrolisis $(\mathrm{mg} / \mathrm{mL})$

$\mathrm{KP}$ akhir = kadar protein kasein setelah dihidrolisis $(\mathrm{mg} / \mathrm{mL})$

\section{Uji aktivitas antioksidan dengan} metode DPPH (Kusumaningtyas et al., 2015)

Larutan DPPH 0,05 mM dibuat dengan melarutkan 1,98 mg DPPH ke dalam $100 \mathrm{~mL}$ metanol 99\%. Protein hidrolisat dilarutkan dalam metanol dengan konsentrasi $1 \mathrm{mg} / \mathrm{mL}$. Sebanyak $1 \mathrm{~mL}$ sampel protein hidrolisat dari kasein ditambahkan dengan $2 \mathrm{~mL}$ DPPH, kemudian didiamkan selama 30 menit. Absorbansi larutan diukur pada panjang gelombang $517 \mathrm{~nm}$. Blanko yang digunakan adalah metanol sebanyak $1 \mathrm{~mL}$. Aktivitas antioksidan dihitung dengan persamaan:

$\%$ Inhibisi $=\frac{\text { A blanko }- \text { A sampel }}{\text { A blanko }} \times 100 \%$

Keterangan:

A blanklo $=$ Absorbansi hasil reaksi larutan DPPH dan metanol 99\%

A sampel $=$ Absorbansi hasil reaksi larutan DPPH dengan protein hidrolisat

Fraksi kasein yang memiliki persentase inhibisi tertingi dibuat seri konsentrasi $1 ; 2 ; 3 ; 4$; dan $5 \mathrm{mg} / \mathrm{mL}$ untuk mendapatkan persamaan regresi linear. Vitamin $\mathrm{C}$ digunakan sebagai standar antioksidan dengan seri konsentrasi 1; 2; 
3; 4; dan 5 ppm. Regresi linear yang diperoleh dalam bentuk persamaan $\mathrm{y}=$ $\mathrm{bx}+\mathrm{a}$ digunakan untuk mencari nilai $\mathrm{IC}_{50}$ (Inhibition Concentration 50\%). Caranya dengan menyatakan nilai y sebesar 50. Nilai $\mathrm{x}$ yang diperoleh dinyatakan sebagai $\mathrm{IC}_{50}$. Langkah selanjutnya adalah penentuan nilai AAI (Antioxidant Activity Index) untuk mengetahui index aktivitas antioksidan. Nilai AAI ditentukan dengan persamaan:

$\mathrm{AAI}=\frac{\text { Konsentrasi DPPH }(\mathrm{mg} / \mathrm{mL})}{\mathrm{IC}_{50} \text { sampel }(\mathrm{mg} / \mathrm{mL})}$

Menurut Scharer dan Godoy (2009) aktivitas antioksidan berdasarkan nilai AAI dikatakan lemah jika nilai AAI < 0,5; aktivitas antioksidan sedang jika $0,5<\mathrm{AAI}<1,0$; aktivitas antioksidan kuat jika 1,0 < AAI $<2,0$; dan aktivitas antioksidan sangat kuat jika nilai AAI > 2,0.

Uji hemolisis (Kusumaningtyas et al., 2015)

Darah ayam ditambah asam oksalat untuk mencegah koagulasi. Darah ayam dicuci dengan 0,01 M Tris- $\mathrm{HCl}(\mathrm{pH}$ $7,4)$ yang mengandung $0,15 \mathrm{M} \mathrm{NaCl}$ (Tris-salin), kemudian disentrifugasi pada $1000 \mathrm{rpm}$. Supernatan dibuang dan pelet dicuci sebanyak 2 kali dengan bufer Trissalin. Suspensi $0,1 \%$ sel darah merah dibuat dengan melarutkan pelet sel darah merah menggunakan Tris-salin. Sebanyak $1 \mathrm{~mL}$ protein hidrolisat dari kasein ditambahkan dengan $1 \mathrm{~mL}$ suspensi sel darah merah $0,1 \%$, lalu diinkubasi selama 2 jam pada suhu $37{ }^{\circ} \mathrm{C}$ kemudian disentrifugasi pada $5000 \mathrm{rpm}$ selama 5 menit. Supernatan diambil dan diukur absorbansinya pada panjang gelombang $540 \mathrm{~nm}$. Tween 80 digunakan sebagai kontrol positif yang mempresentasikan hemolisis $100 \%$ dan Tris-salin sebagai kontrol negatif yang mempresentasikan hemolisis $0 \%$. Pengujian dilakukan dengan 3 kali ulangan. Nilai persentase hemolisis diperoleh dengan menggunakan persamaan berikut:

$$
\% \text { Hemolisis }=\frac{\text { Abs sampel }- \text { Abs kontrol }(-)}{\text { Abs kontrol }(+)} \mathrm{x}
$$

$100 \%$

Keterangan:

Abs kontrol $(-)=$ Absorbansi suspensi eritrosit + tris-salin

Abs kontrol $(+)=$ Absorbansi suspensi eritrosit + tween 80

Abs sampel $=$ Absorbansi suspensi eritrosit + protein hidrolisat kasein/whey

\section{Hasil dan Pembahasan}

Derajat Hidrolisis Fraksi Kasein Hidrolisat

Hidrolisis protein menggunakan enzim adalah cara yang efisien untuk memperoleh protein hidrolisat karena dapat menghasilkan protein hidrolisat 
yang terhindar dari kerusakan asam amino tertentu, seperti triptofan dan glutamin. Menurut Suhartono (2008), hidrolisis protein secara enzimatis merupakan metode yang umum digunakan untuk menghasilkan peptida bioaktif karena memiliki beberapa kelebihan yaitu: tidak mengakibatkan kerusakan asam-asam amino, peptida rantai pendek yang dihasilkan lebih bervariasi (dipeptida dan tripeptida), dan tidak menyebabkan dekomposisi asam amino. Hidrolisis enzimatik merupakan metode yang paling umum digunakan untuk memecah protein sehingga diperoleh peptida bioaktif. Enzim-enzim tersebut memecah protein pada sisi tertentu yang menentukan sekuens, panjang dan bioktivitas peptida yang dihasilkan. Hidrolisis protein menggunakan enzim protease dipengaruhi oleh beberapa faktor seperti suhu, $\mathrm{pH}$, waktu hidrolisis, konsentrasi, dan perbandingan enzim dengan protein. Protease menguraikan protein menjadi molekul yang lebih kecil. Setiap enzim protease memiliki kemampuan berbeda dalam menghidrolisis ikatan peptida.

Hidrolisat protein adalah produk yang dihasilkan dari penguraian protein menjadi peptida dan asam amino melalui proses hidrolisis (Pasupuleti dan Demain 2010). Derajat hidrolisis merupakan rasio jumlah peptida yang dipecah selama hidrolisis terhadap jumlah ikatan peptida yang terkandung dalam protein. Derajat hidrolisis dapat mempengaruhi sifat fungsional dari protein hidrolisat yang dihasilkan (Baharrudin et al., 2016). Data derajat hidrolisis protein hidrolisat dari kasein susu kambing etawa ditampilkan pada Tabel 1.

Tabel 1. Derajat Hidrolisis Kasein Hidrolisat

\begin{tabular}{cc}
\hline $\begin{array}{c}\text { Waktu hidrolisis } \\
\text { (menit) }\end{array}$ & $\begin{array}{c}\text { Derajat hidrolisis } \\
\text { kasein }(\%)\end{array}$ \\
\hline Tanpa hidrolisis & $\mathbf{0}$ \\
\hline 10 & 32,53 \\
\hline 20 & 34,86 \\
\hline 30 & 40,29 \\
\hline 40 & 42,06 \\
\hline 50 & 49,13 \\
\hline 60 & 52,23 \\
\hline
\end{tabular}

Hasil penelitian yang ditampilkan pada Tabel 1 menunjukkan bahwa semakin lama waktu hidrolisis oleh bromelin maka semakin besar persentase derajat hidrolisis. Derajat hidrolisis tertinggi dicapai pada waktu inkubasi 60 menit. Haslaniza et al. (2010) menyatakan bahwa semakin lama waktu hidrolisis, aktivitas proteolitik meningkatkan proses degradasi protein, sehingga diperoleh derajat hidrolisis yang lebih tinggi. Waktu hidrolisis yang berbeda menghasilkan jenis peptida dan asam amino bebas yang 
berbeda, yang dinyatakan dengan besarnya persentase derajat hidrolisis. Derajat hidrolisis merupakan suatu parameter yang menunjukkan kemampuan protease dalam menghidrolisis protein. Semakin tinggi tingkat pemecahan protein menjadi senyawa berantai pendek, derajat hidrolisisnya semakin tinggi. Dewi (2016) dalam penelitiannya menyatakan bahwa hidrolisis protein ikan kayu dengan enzim papain $1 \%$ pada suhu $50{ }^{\circ} \mathrm{C}$ selama 60 menit menghasilkan nilai derajat hidrolisis tertinggi dengan nilai 5,420 $\pm 0,574 \%$.

\section{Aktivitas Antioksidan Kasein}

\section{Hidrolisat}

Uji aktivitas antioksidan dilakukan dengan mereaksikan fraksi kasein hidrolisat dengan larutan DPPH 0,05 mM, kemudian diukur absorbansinya pada panjang gelombang $517 \mathrm{~nm}$. Hasil penelitian menunjukkan bahwa semua fraksi kasein hidrolisat yang diuji menyebabkan menurunnya intensitas warna larutan DPPH, sehingga absorbansinya menurun. Persentase inhibisi fraksi kasein hidrolisat ditampilkan pada Gambar 1.

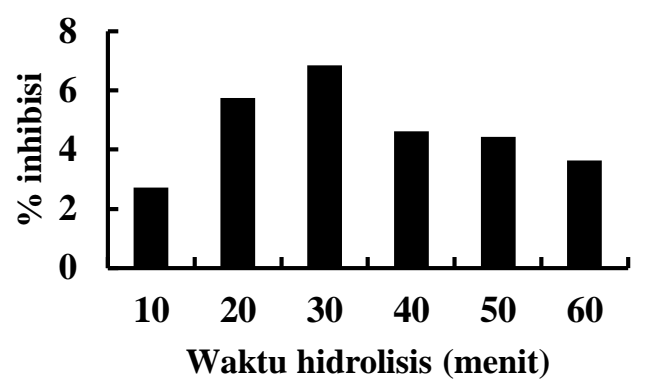

Gambar 1. Grafik aktivitas antioksidan kasein hidrolisat

Hasil menunjukkan bahwa waktu hidrolisis yang berbeda menghasilkan persentase inhibisi yang berbeda. Persentase inhibisi dari waktu hidrolisis 10 menit sampai 30 menit meningkat, dan menurun setelah 30 menit. Hal ini berarti bahwa waktu hidrolisis 30 menit menghasilkan persentase inhibisi tertinggi sebesar 6, 85\%. Aktivitas antioksidan tertinggi dihasilkan oleh kasein hidrolisat pada waktu hidrolisis 30 menit. Hasil yang berbeda didapatkan oleh Dewi (2016) dalam penelitiannya yang menyatakan bahwa aktivitas antioksidan protein hidrolisat ikan kayu menurun, sejalan dengan bertambahnya waktu hidrolisis; aktivitas antioksidan tertinggi dihasilkan pada waktu hidrolisis 15 menit. Samaranayaka (2010) menyatakan bahwa menurunnya aktivitas antioksidan sejalan dengan bertambahnya waktu hidrolisis, karena rusaknya urutan peptida antioksidatif yang terbentuk pada tahap 
awal proses hidrolisis. Klompong et al. (2007) menyatakan bahwa perubahan ukuran peptida yang semakin kecil seiring dengan bertambahnya waktu hidrolisis bertanggung jawab terhadap menurunnya aktivitas antioksidan protein hidrolisat.

Antioksidan merupakan senyawa yang mampu menetralisir atau menstabilkan radikal bebas dengan cara melengkapi kekurangan elektron pada radikal bebas (Kikuzaki \& Nobuji, 1993). Aktivitas antioksidan dalam suatu senyawa dapat dideteksi dengan metode DPPH (1,1-Difenil-2-pikrilhidrazin). Prinsip uji aktivitas antioksidan menggunakan DPPH yaitu adanya pendonor atom hidrogen pada senyawa antioksidan yang bereaksi dengan radikal bebas DPPH (Shon et al. 2003). Reynertson (2007) menyatakan bahwa DPPH merupakan senyawa organik dengan kandungan nitrogen yang tidak stabil. Senyawa ini memiliki absorbansi kuat pada $\lambda$ maksimum $517 \mathrm{~nm}$ dan memiliki warna ungu gelap. Molyneux (2004) menyatakan bahwa adanya senyawa yang dapat mendonorkan atom hidrogen menyebabkan perubahan warna DPPH dari ungu menjadi warna kuning pucat.

Kasein hidrolisat, hasil hidrolisis dengan waktu 30 menit, selanjutnya digunakan untuk menentukan nilai $\mathrm{IC}_{50}$.
Nilai $\mathrm{IC}_{50}$ menyatakan besarnya konsentrasi larutan sampel yang dibutuhkan untuk mereduksi radikal bebas DPPH sebesar 50\%. Vitamin C digunakan sebagai standar antioksidan dengan konsentrasi 1; 2; 3; 4; dan 5 ppm. Kurva penentuan nilai $\mathrm{IC}_{50}$ kasein hidrolisat hidrolisis 30 menit ditampilkan pada Gambar 2, sedangkan kurva penentuan nilai $\mathrm{IC}_{50}$ vitamin $\mathrm{C}$ ditampilkan pada Gambar 3.

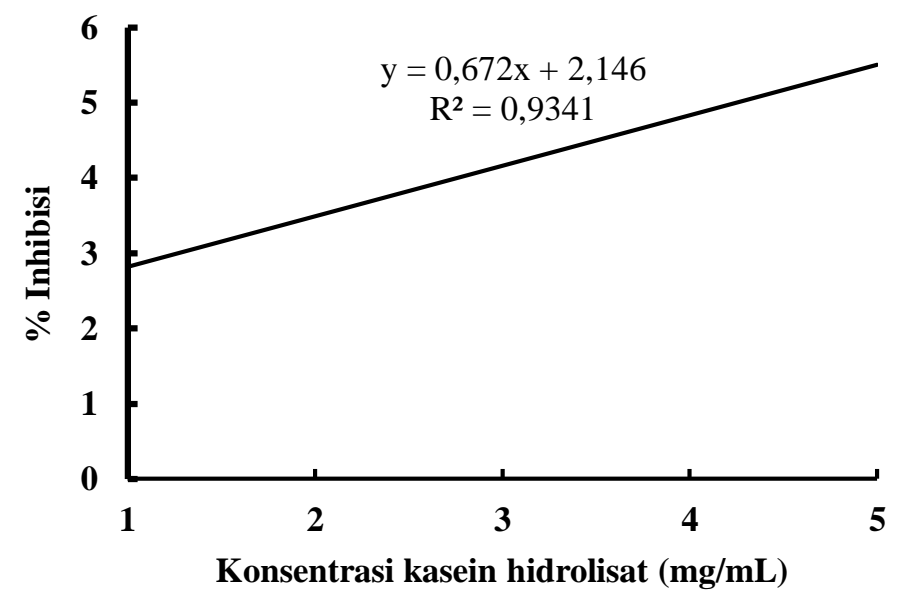

Gambar 2. Grafik penentuan IC 50 $_{50}$ kasein hidrolisat

Hasil diperoleh persamaan regresi linier y $=0,672 x+2,146$. Nilai IC $_{50}$ didapat dengan memasukkan nilai persentase inhibisi $50 \%$ pada persamaan regresi linier tersebut. Hasil perhitungan diperoleh nilai $\mathrm{IC}_{50}$ sebesar $71,21 \mathrm{mg} / \mathrm{mL}$. 


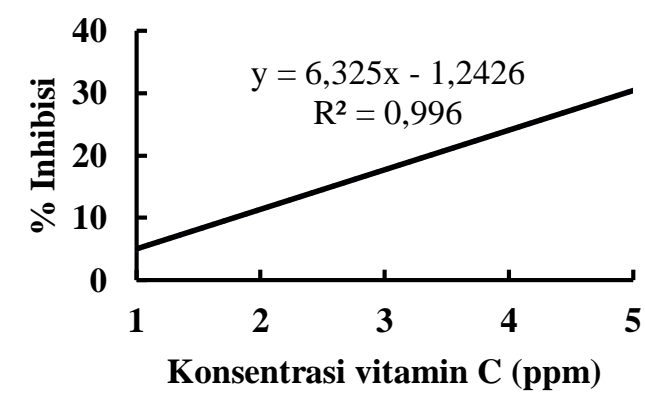

Gambar 3. Grafik penentuan IC $_{50}$ vitamin C

Hasil diperoleh persamaan regresi linier y $=6,325 \mathrm{x}-1,2426$. Hasil perhitungan diperoleh nilai $\mathrm{IC}_{50}$ sebesar $0,008 \mathrm{mg} / \mathrm{mL}$.

Hasil penelitian menunjukkan bahwa persentase inhibisi semakin meningkat dengan semakin meningkatnya konsentrasi kasein hidrolisat yang diuji. Pada konsentrasi kasein hidrolisat yang semakin tinggi terdapat peptida atau asam amino yang bersifat antioksidan dengan jumlah lebih banyak, sehingga jumlah donor hidrogen dari peptida semakin banyak dan bereaksi dengan radikal DPPH membentuk DPPH non-radikal (Hanani et al. 2005). Demikian juga pada vitamin C, semakin tinggi konsentrasinya maka semakin tinggi pula persentase inhibisinya, artinya semakin tinggi pula aktivitas antioksidannya. Nilai $\mathrm{IC}_{50}$ kasein hidrolisat dan vitamin $\mathrm{C}$ ditampilkan pada Tabel 2.

Tabel 2. Nilai IC $_{50}$ Kasein Hidrolisat dan Vitamin C

\begin{tabular}{lc}
\hline Perlakuan & Nilai $\mathbf{I C}_{\mathbf{5 0}}(\mathbf{m g} / \mathbf{m L})$ \\
\hline Kasein hidrolisat & 71,21 \\
\hline Vitamin C & 0,008 \\
\hline
\end{tabular}

Berdasarkan hasil yang ditampilkan pada Tabel 2, diketahui bahwa nilai $\mathrm{IC}_{50}$ kasein hidrolisat lebih besar daripada nilai $\mathrm{IC}_{50}$ vitamin C. Hal ini berarti kemampuan antioksidan dari kasein hidrolisat lebih rendah daripada vitamin C. Nilai IC $_{50}$ digunakan untuk menentukan nilai AAI (Antioxidant Activity Index) agar dapat diketahui klasisifikasi antioksidannya. Nilai AAI ditentukan untuk mengetahui indeks aktivitas antioksidan dari protein hidrolisat kasein dan whey. Nilai AAI diperoleh dengan menghitung rasio konsentrasi DPPH yang digunakan dalam uji terhadap nilai $\mathrm{IC}_{50}$ kasein hidrolisat. Nilai AAI kasein hidrolisat susu kambing etawa dan vitamin $\mathrm{C}$ ditampilkan pada Tabel 3.

Tabel 3. Nilai AAI Vitamin C dan Kasein Hidrolisat

\begin{tabular}{lc}
\hline Perlakuan & Nilai AAI \\
\hline Kasein hidrolisat & 0,278 \\
\hline Vitamin C & 2,475 \\
\hline
\end{tabular}

Berdasarkan data pada Tabel 3 tersebut, nilai AAI vitamin C lebih besar daripada AAI kasein hidrolisat. Scharer dan Godoy (2009) mengklasifikasikan aktivitas antioksidan berdasarkan nilai AAI ke dalam 4 kelompok. Aktivitas antioksidan lemah jika nilai AAI < 0,5, aktivitas antioksidan sedang jika 0,5 < AAI $<1,0$, aktivitas antioksidan kuat jika $1,0<$ AAI $<2,0$, dan aktivitas 
antioksidan sangat kuat jika nilai AAI > 2,0. Berdasarkan hasil tersebut, maka vitamin $\mathrm{C}$ diklasifikasikan sebagai antioksidan sangat kuat, karena memiliki AAI di atas 2,0, sedangkan kasein hidrolisat, tergolong sebagai antioksidan lemah karena nilai AAI nya di bawah 0,5 .

Chalamaiah et al. (2015) menyatakan semakin rendah nilai $\mathrm{IC}_{50}$ semakin baik nilai aktivitas antioksidannya. Nilai $\mathrm{IC}_{50}$ yang tinggi menunjukkan aktivitas antioksidan yang rendah, karena untuk menghambat radikal bebas DPPH sebesar 50\% dibutuhkan konsentrasi yang lebih tinggi.

Dewi (2016) dalam penelitiannya terhadap protein hidrolisat ikan kayu yang dihidrolisis dengan papain $1 \% \quad(\mathrm{w} / \mathrm{w})$ selama 15 menit, memperoleh nilai $\mathrm{IC}_{50}$ sebesar 0,159 mg/mL. Sila dan Bougatef (2016) menyatakan bahwa spesifisitas enzim yang digunakan dalam proses proteolisis merupakan salah satu faktor paling penting dalam memproduksi peptida antioksidan. Bordbar et al. (2013) menyatakan bahwa aktivitas antioksidan sebagai penangkal radikal DPPH dipengaruhi oleh ukuran peptida dan kelarutannya.

\section{Uji Hemolisis Kasein Hidrolisat}

Uji hemolisis adalah uji untuk mengetahui toksisitas peptida karena sensitivitasnya dalam mengevaluasi kerusakan membran sel eukariot (Kusumaningtyas et al., 2015). Hemolisis adalah pecahnya sel membran eritrosit sehingga hemoglobin bebas ke dalam medium sekelilingnya (Kahar, 2017). Prinsip uji hemolisis adalah reaksi antara suspensi eritrosit dengan kasein hidrolisat untuk melihat efek ketahanan eritrosit terhadap kemungkinan terjadinya hemolisis. Tris-salin sebagai kontrol negatif dan Tween 80 sebagai kontrol positif. Hasil reaksi diukur absorbansinya pada panjang gelombang $540 \mathrm{~nm}$. Hasil uji hemolisis ditampilkan pada Tabel 4.

Tabel 4. Persentase hemolisis sel darah merah

\begin{tabular}{ll}
\hline Perlakuan & \% Hemolisis \\
\hline Kasein hidrolisat & 5,66 \\
\hline Tween 80 & 100 \\
\hline Tris salin & 0 \\
\hline
\end{tabular}

Berdasarkan Tabel 4, Tween 80 sebagai kontrol positif mempunyai persentase hemolisis tertinggi sebesar 100\%. Tantradwitiya (2009) menyatakan bahwa nilai absorbansi yang tinggi mengindikasikan semakin banyaknya eritrosit yang mengalami hemolisis. Hemolisis menyebabkan pecahnya sel darah merah dan keluarnya hemoglobin dari membran eritrosit, sehingga 
meningkatkan intensitas warna merah dan nilai absorbansinya semakin tinggi. Trissalin sebagai kontrol negatif mempunyai persentase hemolisis sebesar $0 \%$. Hal ini mengindikasikan bahwa Tris-salin tidak menyebabkan hemolisis pada sel darah merah.

Kasein hidrolisat memiliki persentase hemolisis sebesar 5,66\%. Persentase hemolisis yang kecil pada kasein hidrolisat bermakna tidak menyebabkan hemolisis terhadap eritrosit dan aman untuk diaplikasikan sebagai antioksidan. Hal ini berarti bahwa kasein hidrolisat dari susu kambing etawa yang dihidrolisis dengan enzim bromelin dari daun nanas madu berpotensi untuk dikembangkan sebagai antioksidan di masa depan. Kusumaningtyas et al., (2015) dalam hasil penelitiannya menyatakan bahwa hidrolisat protein dari susu kambing menghasilkan persentase hemolisis sebesar 3,33\%. Zhu et al. (2002) menyatakan bahwa keberadaan suatu senyawa antioksidan di dalam plasma darah dapat mengurangi terjadinya proses kerusakan oksidatif pada sel darah merah. Kekurangan senyawa antioksidan dalam eritrosit merupakan salah satu penyebab tingginya proses oksidasi.

\section{Kesimpulan}

Hidrolisis kasein dari protein susu kambing Etawa dengan bromelin dari daun nanas madu pada kondisi optimumnya menghasilkan fraksi kasein hidrolisat dengan aktivitas antioksidan tertinggi pada waktu hidrolisis 30 menit. Berdasarkan nilai AAI, fraksi kasein hidrolisat tersebut tergolong ke dalam antioksidan lemah. Hasil uji hemolisis menunjukkan bahwa fraksi kasein hidrolisat tidak menyebabkan lisis terhadap sel darah merah, sehingga potensial untuk dikembangkan sebagai antioksidan.

\section{Daftar Pustaka}

Ahn CB, Cho YS, and Je JY. 2015. Purification and anti-inflammatory action of tripeptide from salmon pectoral fin by-product protein hydrolysate. Food Chemistry.168: 151-156.

Baharrudin NA, Halim NRA, and Sarbon NM. 2016. Effect of Degree of Hydrolysis (DH) on The Functional Properties and Angiotensin IConverting Enzyme (ACE) Inhibitory Activity of Eel (Monopterus Sp) Protein Hydrolysate. International Food Research Journal 23(4): 14241431.

Bezerra VS. 2013. Biotechnological Richness of The Northeastern SemiArid Region: Antioxidant Activity of Casein Hydrolysates from Moxotó Goat Milk (Capra Hircus Linnaeus, 1758) Obtained by Papain Action. Food Sci Technol 33(3): 513-520. 
Bollag DM, Rozycki MD, and Edelstein ST. 1996. Protein Methods Second Edition. John Wiley \& Sons. New York. USA.

Bordbar S, Ebrahimpour A., Hamid AA, and Saari N. 2013. The Improvement of The Endogenous Antioxidant Property of Stone Fish (Actynoyga Lecanora) Tissue Using Enzymatic Proteolysis. Biology and Medical Research International 9(1): 15-18.

Chalamaiah M, Jyothirmayi T, Diwan PV, and Kumar BD. 2015. Antioxidant Activity and Functional Properties of Enzymatic Protein Hydrolysates from Common Carp (Cyprinus Carpio) Roe (Egg). Journal Food Science and Technology 52(9): 5817-5825.

Darwis AA dan Sakara E. 1990. Isolasi Pemurnian dan Karakterisasai Enzim. IPB Press. Bogor

Dewi NM. 2016. Peptida Antioksidatif dari Hidrolisat Protein Ikan Kayu. Skripsi. Institut Pertanian Bogor. Bogor.

Hanani E, Munim, A dan Sekarini R. 2005. Identifikasi Senyawa Antioksidan dalam Spons Callyspongia $\mathrm{Sp}$ dari Kepulauan Seribu. Majalah Ilmu Kefarmasian. 2(3): 127-133.

Haslaniza H, Maskat MY, Wan Aida WM, and Mamot S. 2010. The effects of enzyme concentration, temperature and incubation time on nitrogen content and degree of hydrolysis of protein precipitate from cockle (Anadara granosa) meat wash water. International Food Research Journal. 17: 147-152.

Kahar H. 2017. Pengaruh Hemolisis Terhadap Kadar Serum Glutamate Pyruvate Transaminase (SGPT) Sebagai Salah Satu Parameter Fungsi Hati. The Journal Of
Muhammadiyah Medical Laboratory Technologist 1(2): 38-46.

Kikuzaki H, and Nobuji N. 1993. Antioxidant Effect of Some Ginger Constituents. Food Scince. 58: 14071410.

Klompong V, Benjakul S, Kantachote D, and Shahidi F. 2007. Antioxidative Activity and Functional Properties of Protein Hydrolysate of Yellow Stripe Trevally (Selaroides Leptolepis) As Influenced by The Degree of Hydrolysis and Enzyme Type. Food Chemistry 102(7): 1317-1327.

Kumar S, Chouhan S, Sanghi A, and Teotia UVS. 2013. Antioxidative Effect of Yak Milk Caseinate Hydrolyzed with Three Different Proteases. Vet World 6: 799-802.

Kusumaningtyas E, Widiastuti R, Kusumaningrum HD, dan Suhartono MT. 2015. Aktivitas Antibakteri dan Antioksidan Hidrolisat Hasil Hidrolisis Protein Susu Kambing dengan Ekstrak Kasar Bromelin. Jurnal Teknologi dan Industri Pangan 26(2) :179-188.

Lestari D dan Soesilo VV. 2017. Aktivitas Antibakteri Peptida Kasein Susu Kambing Hidrolisis oleh Papain terhadap Pseudomonas Aeruginosa. Jurnal Ilmu Pangan dan Hasil Pertanian 1(2): 81-92.

Li Z, Jiang A, Yue T, Wang Y, and Su, J. 2013. Purification and Identification of Five Novel Antioxidant Peptidas from Goat Milk Casein Hydrolysates. J Dairy Sci. 96: 4242-4251.

Martínez R, Torres P, Meneses MA, Figueroa JG, Álvarez JAP, dan and Martos VM. 2012. Chemical, technological and in vitro antioxidant properties of mango, guava, pineapple and passion fruit dietary 
fibre concentrate. Journal Food Chemistry. 135: 1520-1526.

Molyneux P. 2004. The Use of The Stable Free Radical Diphenylpicrylhydrazil (DPPH) for Estimating Antioxidant Activity. Journal Science and Technology. 26(2): 211-219.

Mora L, and Toldrá F. 2014. Proteomic identification of antioxidant peptides from 400 to 2500 da generated in Spanish dry-cured ham contained in a size-exclusion chromatography fraction. Journal Food Res. Int.56: 6876.

Park YW, Ju'arez M, Ramos M, and Haenlein GFW. 2007. Physicochemical Characteristics of Goat and Sheep Milk. Small Ruminant Res 68: 88-113.

Pasupuleti VK and Demain AL. 2010. Protein Hydrolysates in Biotechnology. Springer Publishing. Inggris

Reynertson KA. 2007. Phytochemical Analysis of Bioactive Constituens from Edible Myrtaceae Fruit. Dissertatio. The City University Of New York. New York.

Sabahelkheir MK, Faten MM, and Hassan AA. 2012. Amino acid composition of human and animal's milk (camel, cow, sheep and goat). ARPN J Sci Technol. 2: 32-34.

Samaranayaka AGP.2010. Pacific Hake (merluccius productus) Fish Protein Hydrolysates With Antioxidative Properties. Thesis. Vancouver (CA): Faculty of Graduate Studies (Food Science). University of British Columbia. Columbia.

Scharer R and Godoy HT. 2009. Antioxidant Activity Index (AAI) by the 2,2-diphenyl-1-picrylhydrazyl. Method. Food Chem 112: 654-658.
Shon MY, Kim TH, and Sung NJ. 2003. Antioxidants and Free Radical Scavenging Activity of Phenllinus baumii (Phellinus of Hymenochaetaceae) extracts. Food Chemistry. 82(4): 593-597.

Sila A and Bougatef A. 2016. Antioxidant Peptides from Marine by-Products: Isolation, Identification and Application in Food Systems. A Review. Journal of Functional Foods 21: 10-26.

Suhartono M T. 2008. Protease. IPB Press. Bogor.

Szwajkowska M, Wolanciuk A, Barlowska J, Krol J, and Zygmunt L. 2011. Bovine Milk Proteins as The Source of Bioactive Peptidas Influencing the Consumers Immune System. Anim Sci Pap Rep. 29: 269280.

Tantradwitiya K. 2009. Hemolisis Eritrosit In Vitro serta Kapasitas Antioksidan Pepes Ikan Mas Riadiasi dan Non Iradiasi. Skripsi. Fakultas Teknologi Pertanian. Institut Pertanian Bogor. Bogor.

Yoshida S, Wei Z, Shinmura Y, and Fukunaga N. 2000. Separation of Lactoferrin-a and -b from Bovine Colostrum. J Dairy Sci. 83: 22112215.

Zhu QY, Holt RR, Lazarus SA, Orozco TJ, and Kenn CL. 2002. Inhibitory Effect of Cocoa Flavanols and Procyanidin Oligomers on Free Radical-Induced Erythrocyte Hemolysis. Experimental Biology Medicine. 22(5): 321-329. 